
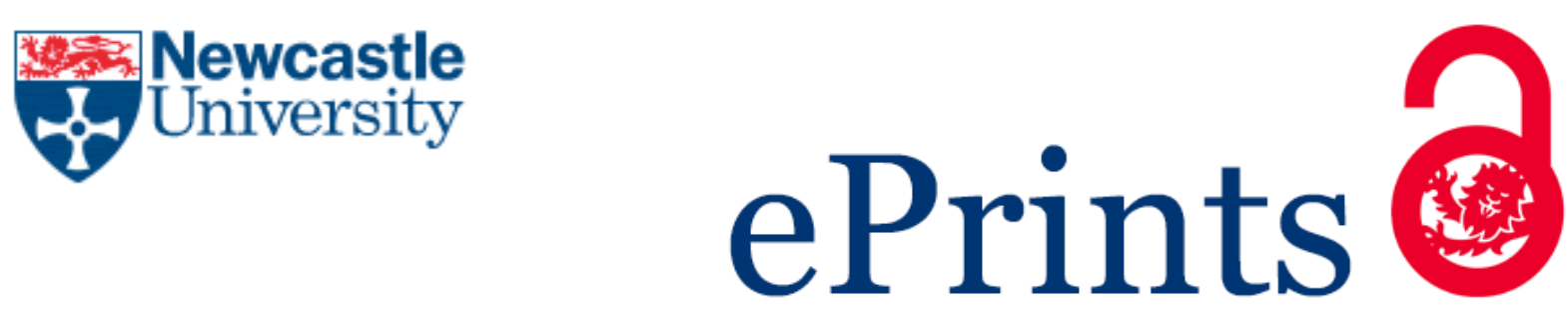

\title{
Munro I.
}

Organizational Ethics and Foucault's 'Art of Living': Lessons from Social Movement Organizations.

Organization Studies 2014, 35(8), 1127-1148.

\section{Copyright:}

This is the author's accepted manuscript of an article published in its final definitive form by Sage Publications Ltd, 2014.

Link to published article:

http://dx.doi.org/10.1177/0170840614530915

Date deposited:

$12 / 01 / 2015$

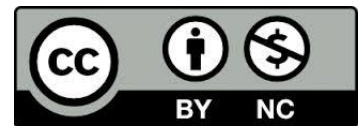

This work is licensed under a Creative Commons Attribution-NonCommercial 3.0 Unported License 


\title{
Organizational Ethics and Foucault's 'Art of Living': Lessons from Social Movement Organizations
}

\author{
By Iain Munro \\ Newcastle University Business School, Newcastle, UK
}

Published in Organization Studies, 2014

\begin{abstract}
This article develops Foucault's later work on ethics and his concept of ethical askesis in the transformation of the self as a new approach to understanding organizational ethics. Scholars within the field of management and organization studies have already proposed the development of a Foucauldian approach to ethics, but the precise nature of such an 'art of living' has yet to be clarified. To address this gap in the literature this article builds on Foucault's theoretical and practical interest in the work of historical and contemporary social movement organizations. The article investigates the role that social movement organizations play as crucibles for the creation of new forms of organizational subjectivity and novel ethical practices. In this way the article develops a synthesis between the Foucauldian scholarship and social movement organization theory. The contribution of the article shows how social movement organizations act as sites for the creation of novel organizational subjectivities and ethical practices, and reconceptualizes organizational ethics in Foucauldian terms as a form of ethical askesis to transform the self.
\end{abstract}

\section{Keywords}

askesis, cynicism, ethics, Foucault, social movement organizations, subjectivity

\section{Introduction}

This paper develops the idea of 'askesis' to reconceptualize organizational ethics, where ethical askesis plays a crucial role in the constitution of alternative, sometimes radical, forms of organizational subjectivity. Recent research within the field of organization studies has focused upon Foucault's later works on ethics and its relevance to modern management practice. This research has called for an investigation of organizational ethics in terms of a 'care of the self' and new ways of 'acting and being' (Chan \& Garrick, 2002; Hancock, 2008; Iedema \& Rhodes, 2010; Kosmala \& McKernan, 2011; Randall \& Munro 2010; Starkey \& Hatchuel, 2002). This approach frames the employee as an 'active' ethical subject who is responsible for their own self-creation (Ibarra- Colado, Clegg, Rhodes \& Kornberger, 2006; Starkey \& Hatchuel, 2002). However, as yet relatively little scholarly attention has been devoted to the possibilities for ethical self-creation in terms of concrete organizational practices.

One of the most popular themes that has been taken up by management scholars from Foucault's late work on ethics is the idea that the self can be transformed into a work of art (Bardon \& Josserand, 2011; Ibarra-Colado et al., 2006; Kosmala \& McKernan, 2011; Loacker \& Muhr, 2009). Some have objected that this conception of ethics is overly aesthetic and little more than dandyism (Hadot, 1995; Hancock, 2008). Contu (2008) observes that the call for understanding life as a developmental project is now the mainstay of management gurus and lifestyle consultants. She criticizes the notion of the 'care of the self' for its political naiveté, describing it as a kind of 'decaf resistance'. Contu (2008, p. 274) argues that 'Decaf 
resistance, just as decaf coffee, makes it possible for us to enjoy [resistance] without the costs and risks involved.' With due consideration given to the limits of such 'decaf resistance', it is the contention of the present paper that the radical potential of the 'care of the self' has yet to be revealed. Indeed, Edward Barratt's (2008, p. 534) review of Foucault's late work has highlighted the need to 'correct one of the curious omissions to Foucault's reception in organization and management studies - the activism at the heart of his project'. The present paper demonstrates the radical potential of the care of the self in terms of the 'activist' practices of the self of social movement organizations.

Barratt is one of the few scholars to have highlighted the potential of the activist project to enrich our conception of organizational ethics and 'our capacity to imagine other ways of organizing' (Barratt, 2008, p. 523). His analysis only briefly alludes to possible avenues of investigation, commenting on the role of social movement organizations (SMOs) in developing a more 'autonomous' existence. The present paper addresses this 'curious omission' within organization studies and, furthermore, it shows that Foucault's research on activism provides an excellent starting point to flesh out precisely what an art of living entails for organizational practice. This research gap is addressed in the ensuing analysis by developing the concept of 'ethical askesis' to reveal possibilities for self-creation in organizations beyond exploitative neoliberal mechanisms of identity formation.

Bluhdorn (2006) has argued that social movements have a great deal to teach us about the creation of subjectivity, where he notes that such movements may be the only forum for the 'reconstruction of the self' beyond the hegemonic institutions of neoliberal capitalism. We might turn to Weber's classic study of different Protestant sects in The Protestant Ethic and the Spirit of Capitalism for an excellent precedent that shows how social movement organizations can dramatically influence our sense of self both within and outside work. Social movement theorists have noted that the goal of many movements is not just freedom from oppression but involves the freedom to create new ways of living and the 'freedom to be' (Cerulo, 1997; Melucci, 1989). In this respect, Böhm, Spicer and Fleming (2008) show that existing research in organization studies has tended to focus upon identity formation within the workplace, but has neglected a whole range of active resistance that has been mobilized outside the workplace, particularly within the domain of social movements.

Spicer and Böhm (2007) contend that social movement organizations act as an important plat- form for questioning the neoliberal discourse of management. They explain the success of social movement organizations in terms of their formation of different ethical ideals, and the 'attempt to collectively create and experiment with alternative identities, aspects of the symbolic economy and cultural innovation' (Spicer \& Böhm, 2007, p. 1675). Following from this insight, I investigate the extent to which social movement organizations act as crucibles for the development of alternative ethical practices in organizations and different possibilities for what Foucault termed 'arts of living'.

The theoretical contribution of this paper develops Foucault's concept of 'ethical askesis' in terms of its crucial role in the constitution of alternative forms of organizational subjectivity. The existing scholarship in organization theory has already provided a rigorous account of the ways that worker subjectivities are controlled and disciplined by modern corporations that are framed by an ideal image of the productive employee (Covaleski, Dirsmith, Heian \& Sajay, 1998; Grey, 1994; McKinlay, 2002, 2012; Miller \& O'Leary, 1987; Rose, 1990; Savage, 1998; Starkey \& Hatchuel, 2002; Townley, 1994). However, rather less research has been 
undertaken into the existence of alternative possibilities for self-creation beyond these disciplinary mechanisms. The present article addresses this research gap by investigating social movement organizations as a rich source for the evolution of such alternative forms of organizing which are based upon the creation of different forms of self-discipline - an alternative 'askesis'.

This paper demonstrates that social movement organizations have developed distinctive forms of self-discipline in order to challenge the dominant apparatus of power. The paper shows that social movement organizations are grounded in very particular forms of 'askesis' including (i) bearing witness and the 'true life', (ii) direct action, (iii) the care of the self and asceticism and (iv) the use of pleasure. These ethical exercises have been developed by SMOs to create 'agents capable of challenging the status quo' (Scully \& Creed 2005, p. 313). In contrast to existing social movement theory which has focused on the material and institutional resources of SMOs (Campbell, 2005; McAdam \& Scott, 2005), this paper focuses on forms of ethical self-discipline that are required for the mobilization of SMOs, or what Soule (2012) has termed their 'spiritual resources'. The contribution of this inquiry is threefold: (i) it provides a clear account of the concept of askesis as a practice of ethical self-discipline; (ii) it identifies four key forms of 'ethical askesis' in social movement organizations as micro-emancipatory practices that create agents capable of changing the status quo; and (iii) it shows the potential of asceticism and other forms of askesis in the struggles of social movement organizations to create new ways of organizing.

The paper is structured as follows. First, it begins by outlining a critique of the modern neoliberal subject, showing that it is a free and ethical being in only a very restrictive economic sense. Following from this critique the paper will unearth parts of Foucault's genealogy of the self which have thus far been neglected within the field of management and organization studies, but which can provide a rich source of material for a more detailed understanding of organizational ethics. This account of ethics reveals the importance of the role of 'ethical askesis' in the development of new forms of subjectivity and organizational ethics. This begins with an account of the creation of novel forms of subjectivity in ancient schools of ethics, which serves as a basis for a more detailed study in the second half of the paper of forms of ethical askesis in contemporary social movement organizations. This paper argues that social movement organizations are characterized by inventive forms of 'ethical askesis', which can be found within a diversity of modern SMOs such as Amnesty International, Greenpeace, the Occupy movement and the Slow Food Society, among others. The final section of the paper considers the extent to which the 'ethical askeses' of social movement organizations can enrich our understanding of ethics and micro-emancipation in organizations.

\section{Ethics as an Art of Living in Contemporary Neoliberalism}

Within the field of organization studies numerous scholars have critically discussed the control of worker subjectivity, drawing on a Foucauldian perspective (Covaleski et al., 1998; Halsall \& Brown, 2013; McKinlay, 2002, 2012; Miller \& O’Leary, 1987; Miller \& Rose, 1988; Savage, 1998; Starkey \& Hatchuel, 2002; Townley, 1994). These studies have shown a range of practices for the discipline and control of worker subjectivity such as the use of 'confessional practices' in modern performance appraisal techniques to encourage workers to enumerate their performance failings (Findlay \& Newton, 1998; Townley, 1994) and the use of the professional career ladder as a device for the 'correction' of moral character (Grey, 1994; McKinlay, 
2002, 2012; Savage, 1998). Halsall and Brown (2013, p. 238) have argued that pseudo-religious ascetic practices have reappeared in modern organizations as a 'continual test of commitment to organizational culture'. Techniques of motivation and cultural control have also been criticized for espousing a view of worker subjectivity where 'the language of autonomy, creativity, and self-actualization in the work-place is illusory and the reality is one of psychological manipulation and control' (Kosmala \& McKernan, 2011, p. 386; also, see Rose, 1990, pp. 55-119). Foucault's (2008) own analysis of modern neoliberalism suggests that there are good reasons to question the forms of ethical subjectivity being espoused under the neoliberal project. He highlighted a fundamental contradiction within the neoliberal discourse between its pursuit of a free economic and political subject and at the same time a subject that will respond only according to an economic rationality of utility maximization and self-investment, a self that in his words was 'eminently governable' (Foucault, 2008, p. 270).

While there has been much research within management and organization studies following Foucault's studies of systems of power and domination (e.g. Burrell, 1988; Clegg, 1994, 1998; Knights, 2002; Townley, 1994), his genealogical studies of forms of counter-conduct and alternative forms of ethics have received far less attention. Drawing on Foucault's analysis, Dilts (2011, p. 145) has framed a moral impasse concerning modern neoliberal subjectivity by highlighting how neoliberal discourse reduces the self merely to 'a machine for the production of an income,' rather than appreciating it as an end in itself. Dilts turns to the work of the later Foucault who not only addressed this contradiction at the heart of the neoliberal project but explored alternative conceptions of the self that can be used to question existing conceptions of the liberal or neoliberal Homo oeconomicus. In a similar vein, Micki McGee (2005, p. 160) has criticized the entrepreneurial discourse on the self, observing that it is particularly weak in its 'cultivation of new vocabularies' and is unimaginative in the possibilities it presents for self-creation and creating new possibilities for others. She observes that this discourse tends to recycle white male stereotypes of the good life that are premised on a huge network of free labour performed by women, especially in the domestic realm. Despite these critical remarks, McGee's (2005, p. 23) commentary on neo- liberal self-help culture argues that 'the pursuit of individual self-invention continues to hold radical possibilities, particularly when one's own pursuit of self-invention confounds existing societal expectations'. In contrast to the narrow and impoverished view of the self expounded in neoliberal discourses on the entrepreneur, she proposes the extraordinary life of the civil rights activist Malcolm $\mathrm{X}$ as being exemplary of an art of living.

Within the field of organization studies, calls for practising ethics as an 'art of living' have suggested a number of different ways by which this might be accomplished. Foucault himself did not advocate a particular ethical position beyond a description of his own personal ethic as a kind of 'pessimistic activism' (Foucault, 1997). His friend and colleague Paul Veyne (2010) has proposed that we understand Foucault's approach as comparable to the samurai ethic but there is no suggestion here that such a position should be universalized, quite the contrary. Scholars within the field of management and organization studies have picked up on different threads within Foucault's works on ethics. Some have highlighted the fact that an art of living prioritizes experimental 'practices of the self' in contrast to obedience to formal codes of ethics (Loacker \& Muhr, 2009; Kosmala \& McKernan, 2011; McMurray, Pullen \& Rhodes, 2010; Weiskopf \& Willmott, 2013). Others have highlighted the significance of ethical practices that create an 'active' self-relation in contrast to a docile or 
normalized self-relation (Ibarra-Colado et al., 2006; Iedema \& Rhodes, 2010; Randall $\&$ Munro, 2010). One of the first scholars to introduce a Foucauldian ethics into the field of organization studies was Edward Wray-Bliss (2002), who suggested that such an approach requires questioning prevailing conceptions of the self and normality, where the personal is necessarily a political issue. In common with a number of other scholars in the field Wray-Bliss observed the importance of a critical attitude to processes of normalization and expert authority in such an ethics (see also Starkey \& Hatchuel, 2002; Kosmala \& McKernan, 2011; Randall \& Munro, 2010).

In the existing literature few studies clearly articulate specific practices when it comes to defining precisely how we might engage in ethical practices that constitute an art of living. Iedema and Rhodes (2010) have developed a case study of doctors engaged in a practice of intense self- surveillance in order to raise levels of hygiene in their hospital, which they argue transcended mere obedience to a code and required active self-formation. This study raises an issue of some significance to the present inquiry concerning the important role of self-discipline in the formation of both 'docile' and 'active' subjects. Iedema and Rhodes convincingly demonstrate that such practices of self-surveillance can create active rather than docile ethical subjects among healthcare professionals; however, they do not address how this might transcend medicalized forms of normalization (see Foucault, 1994). Randall and Munro (2010) have also looked to the medical profession for examples of the "care of the self', which can be found in practices of care in voluntary organizations. This study investigated how practical exercises for self-mastery were co-created by clients and voluntary staff as a 'care of the self' beyond the normalizing strictures of statutory health care. Starkey and Hatchuel (2002) have advocated another potentially fruitful avenue for the development of an art of living in terms of sporting activities that can constitute practices of 'non- dogmatic normativity'. Sporting communities offer intriguing possibilities for pursuing an art of living detached from workplace domination. Nevertheless, these practices are often bound up with capitalist norms concerning the priority of competition and the increasing commercialization of social life, so even sports may be considered to be a part of the normalizing apparatus of post- industrial capitalism (Sage, 1990). A common theme of these nascent studies is a concern for the creation of an 'active' ethical subject, but as yet this idea has been advanced somewhat tentatively and is yet to be developed into a clear theoretical framework.

These existing studies within the field of organization studies reveal that the conceptual development of Foucauldian ethics for management and organization studies is still very much in embryonic form. I now turn to Foucault's own genealogical inquiries in order to identify the possibilities and limitations of ethics conceived as 'an art of living' within organizations. In contrast to the existing Foucauldian scholarship within the organization studies literature, this inquiry highlights the importance of ethical askesis for the art of living and explores its potential for developing an alternative ethics for organization theory.

\section{The Ethics of Dissent in Ancient Greece}

We should be clear that Foucault's project was not to resurrect long-dead concepts that were used to educate the Greek aristocracy, and that he was highly sceptical of the accounts that he analysed in his genealogy of ethics. This scepticism is clear from his notes on ancient systems of ethics where he remarked that 'All of antiquity seems to me to have been a "profound error"" (Foucault, 2005, p. 531). In an interview concerning the genealogy of ethics he described the hierarchical, masculine qualities 
of ancient ethics as being 'quite disgusting' (Foucault, 1997, p. 258). With these caveats in mind we should be wary of drawing lessons from a genealogy of ethics for application in the modern world, particularly in the light of contemporary hegemonic struggles.

A crucial element of Foucault's genealogy of subjectivity is his concept of 'ethical askesis' and the role of different forms of askesis in the historical evolution of different forms of subjectivity. Foucault (2005, p. 16) defined this important concept as 'a work of self on the self, an elaboration of the self by the self, a progressive transformation of the self by the self for which one takes responsibility in a long labor of ascesis (askesis)'. In contrast to ethical codes, which simply demand obedience to their dictates, 'the care of the self [requires one] to attend effectively to the self, and to exercise and transform oneself' (Foucault, 1985, p. 73). The concept of ethical askesis should not be conflated with asceticism only, and different forms of ethical askesis are possible. Foucault's genealogical studies reveal that the askesis of the ancient Greeks was directed towards self-mastery, where the ethical exercises were supposed to 'equip' the practitioner for everyday life. Hadot (1995), whose work Foucault drew upon heavily, defined askesis as exercises that were developed so that their practitioners can learn both how to live and how to die. Foucault's genealogical studies of ethical askeses demonstrated that such arts of living were implicated in the government of everyday life and, conversely, in the attempts to resist such government (which he termed 'counter conducts'). Ethical exercises for selftransformation are thus aimed to equip the practitioner in a particular way of living.

Foucault's genealogy of the ethics of ancient Greece and Rome surveys a wide range of philosophers including the works of Plato, Aristotle, Epictetus, Seneca, Marcus Aurelius, among others, and various schools of ethics, particularly those of the Stoics and the Cynics. Many of these schools were a key part of the prevailing social order and their representatives were often city leaders or the advisors of such leaders (the hegemon). He observed that the ancient Greeks believed that only those who could master themselves could properly be the masters of others. Greek and Roman ethics were very much conceived as an ethics for the ruling class, and how the masters could conduct themselves in order that they might also conduct others is key to this ethics. Foucault certainly did not wish to resurrect such an ethics in which domination was a key theme that ran throughout its practices. This is clear not only in direct statements to this effect that he made in interviews, but also in his final lecture course on the Cynics. The Cynic school of philosophy is one of the first instances of a widespread anti-institutional ethic that was concerned with a critique of the prevailing social order. This school is of particular interest because of the way that it mobilized a certain form of asceticism in its critique of the social and institutional order. With the Cynics the mastery of the self was required not in order to master others, as it did in Stoic philosophy, but as an act of permanent critique of the prevailing social order. Foucault (2011, p. 170) summarized the account of the way of life of the Cynic found in ancient commentaries in the following manner:

'The Cynic is the man with the staff, the beggar's pouch, the cloak, the man in sandals or bare feet, the man with the long beard, the dirty man. He is also the man who roams, who is not integrated into society, has no household, family, hearth or country... and he is also a beggar.'

The Cynic is so named because his life resembled that of a dog (Kyon); it is a life led in the open, it is a life led in accordance with the dictates of one's animal desires, 
shamelessly eating, shitting and fucking out in public. But at the same time it is a highly stylized and ascetic way of life. The Cynic lived in abject poverty, he lived in the open, subject to the vagaries of the weather, he lived outside the social order, apart from his family and other social groups. And moreover, he devoted his time to converting others to this way of life, 'barking' at them like a dog. Foucault highlighted the strict asceticism of Cynicism, where the Cynic 'gives his whole life as a test' (Foucault, 2011, p. 194). Humour also played an important role in the social criticism performed by the Cynic. To humiliate Diogenes and his dog-like existence, a citizen once threw him a bone to chew on, to which Diogenes responded by walking over to the man and urinating on him.

Whereas many schools of ancient ethics aimed to educate the ruling elite of the city, the Cynical school was unusual in being universalist in orientation and explicitly critical of social elites. Cynicism was explicitly formulated in opposition to the prevailing social order. It manifested characteristics that were both antihierarchical and anti-institutional. ${ }^{1}$ It also exhibited a peculiar relationship with the truth, which Foucault referred to as 'the scandal of the truth'. This scandal was deeply bound up with revealing the animal nature of human beings and contrasting it with the hypocrisy of civilized morality. Foucault's genealogy traces the mutation of ethical practices from the Cynic school of philosophy to the much later rebellions of the Protestant Reformation, and finds them alive and well in the social movements of more recent history. He observed that from the Cynics to modern revolutionary social movements a key practice of the self has entailed breaking with the prevailing conventions, habits and values of society and 'bearing witness' through one's way of life. Foucault drew a parallel between Cynicism and revolutionary modes of life on the grounds that both highlighted what he termed the 'scandal of the truth' and both were aimed explicitly at the transformation of society and a transvaluation of values. He explained the importance of this distinctive form of ethical askesis by stating that 'one's life bears witness, breaks, and has to break with the conventions, habits, and values of society' (Foucault, 2011, p. 184). Here we have a direct connection between ancient Cynicism and its conception of leading the true life with modern social movement organizations and their conception of leading a true life, a point that will be returned to in greater detail later in this paper. Indeed, Foucault claimed that the theme of the scandal of truth is one that continually resurfaces throughout his genealogical studies of ethics, most especially in his historical studies of dissent. We will now turn to another major ethics of dissent which appears in Foucault's genealogy, in his study of the rise of pastoral power and the crucial role of asceticism in heretical Christian sects opposed to this new power.

\section{Ethical Askesis and 'Counter Conduct' in Religious Social Movements}

The term 'counter-conduct' is one of many neologisms coined by Foucault to distinguish his conception of power and resistance from existing conceptual frameworks. He defined this phrase in relation to his concept of governmentality, which entails all those techniques, discourses and programmes created within a society for 'the conduct of conduct'. What was at stake in the revolts of counterconduct that were associated with the rise of Protestantism was as much the creation of radical new forms of subjectivity as it was with political or economic issues. Foucault's historical analysis of these radical social movements shows that the question of subjectivity is absolutely central to certain forms of ethical and political dissent. While Foucault was sceptical of grand claims pertaining to emancipation, he envisaged a form of critique in terms of different forms of counter-conduct and 'the 
historical practice of revolt' (Foucault, 2007a, p. 75). Arnold Davidson's (2011) discussion of the concept of counter-conduct has identified this as being an undervalued aspect of Foucault's work, which provides a 'conceptual hinge' linking his political studies with his work on ethics.

Foucault's (2007b) analysis identified the role of asceticism as crucial in the formation of radical subjectivities, where an ideal of purity was aimed at through a set of ascetic exercises. This asceticism was somewhat different to that practised by the various ancient Greek schools, where the Christian askesis involved the mortification of the flesh in imitation of Christ's own suffering. Asceticism was thus not aimed primarily at the mastery of the self, but at the complete renunciation of the body and the self. The ascetic exercises of these Christian sects were anti-institutional in that no external guide was required for the exercise of renunciation, where the individual acted as their own guide in a gradual process of purification. Counter-conducts involved the formation of communities which propagated distinctive forms of religious life outside the dictates of the official Church. Foucault noted the emergence of a diverse number of communities such as the Anabaptists, the Brethren of the Free Spirit and the Society of the Poor, all of which propagated their own peculiar heresies. These communities challenged the pastoral authority of the Church in a variety of ways, such as by introducing lay confession, by refusing the sacrament, by refusing the baptism of children and by selecting the poorest or most debased among them to be their leader. These communities often challenged the status of the most oppressed members of society, particularly the subordinate status of women. Foucault explained that the Christian church was not itself formed around such an ascetic ideal, and that the new asceticism of these groups was radical in its challenge to the prevailing institutions of Christian pastoral power. These communities presented a challenge to basic institutions of social control including the family, the Church, feudalism and the merchant bourgeoisie. Each sect developed its own distinctive ascetic practices and conceptions of the self that gradually became involved in what Foucault (2007b) described as a tactical struggle whose practices were adopted either in the new Protestant church or incorporated in modified form within Catholicism itself.

He argued that these revolts and the period of the Reformation were as much about 'a struggle for a new subjectivity' as about the fight against religious and political oppression (Foucault, 1982, p. 213). Incidentally, Foucault's short account of these revolts takes a slightly different tack from Weber's classic account set out in The Protestant Ethic and the Spirit of Capitalism. Weber's analysis follows the transition of certain religious ideals and practices from 'monastic asceticism' to what he described as 'worldly asceticism'. Here Weber takes Benjamin Franklin and his table of strictly utilitarian virtues as his exemplar, in which one can see a direct link between religious ascetic practice and labour as a form of ascetic practice. Labour was proposed as being 'the specific defence against all those temptations of which Puritanism united under the name of the unclean life' (Weber, 1939, p. 105). Weber's analysis as it is presented in his book on the Protestant ethic is focused on how these social movements became re-institutionalized within the Church and more generally incorporated as a part of the 'spirit of capitalism'. ${ }^{2}$ In contrast, Foucault focused on the anti-institutional force of heretical social movements.

The tactics of counter-conduct vary depending upon the particular strategies of government with which they are confronted. In the ancient world the practice of counter-conduct took the specific form of Cynicism, whereas with the imposition of Christian pastoral power it took the form of a proliferation of Protestant heresies (Davidson, 2011). Foucault (2007b) himself traced a line from the forms of counter- 
conduct that developed in the Middle Ages to more modern forms of revolutionary social movement. He observed that these historical events are not entirely unrelated and that the social movement organizations that fostered forms of counter-conduct in the Reformation were also active in both the American Revolution (e.g. Quakerism) and the French Revolution (e.g. Methodism), and these movements continue to be active in a modulated form in today's SMOs. The ethical askeses developed by these early religious organizations have been highly influential in the development of modern social movement organizations such as Greenpeace and Amnesty International, among others. As Foucault revealed, in these organizations asceticism exhibited a strongly anti-institutional ethic and helped create resistant forms of subjectivity. We shall now turn to an analysis of the ethical askesis in modern social movement organizations to bring our inquiry more clearly into the present.

\section{Ethical Askesis in Social Movements: Protest as Self-Forming Activity}

Foucault's genealogical studies of ethics highlight the relationship between power and the self, where any project of resistance must take into account the process of selfformation. His genealogical studies revealed that 'there is no first or final point of resistance to political power other than the relationship one has to oneself' (Foucault, 2005 , p. 252). This genealogical approach to understanding the self highlights potentially 'reversible relationships' that provide points of resistance to the prevailing mechanisms of power (Foucault, 2005, p. 252). The notion of askesis is a crucial element in the emergence of resistance to the mechanisms of power. In his exposition of the emergence of early forms of governmentality Foucault (2007b, pp. 207-208) explained that

asceticism is rather a sort of tactical element, an element of reversal... utilized against these [governmental] structures of power. Asceticism is a sort of exasperated and reversed obedience that has become egoistic self-mastery. Let's say that in asceticism there is a specific excess that denies access to an external power.

The concept of ethical askesis is therefore central to understanding Foucault's conception of resistance and his identification of elements of reversibility in emerging structures of power, particularly with respect to the role of social movements.

Social movement theory has analysed ethical issues in a range of diverse but related ways, for example, in terms of emotional 'moral shock' (Jasper, 1998; Jasper \& Poulson, 1995), the framing of perceived injustice (Goodwin, Jasper \& Polletta, 2007; McAdam, McCarthy \& Zald, 1996; Valverde, 1999) and, more generally, the sources of legitimization in the framing process (Snow, Rocheford, Worden \& Benford, 1986; Tarrow, 2011). Melucci's (1996) commentary on the ethics of social movements refers briefly to the significance of self-transformation in his discussion of 'spiritual' social movements, particularly in the case of more fundamentalist groups. For understandable reasons, social movement theory has tended to focus on ethics in terms of the issue of justice, rather than in terms of processes of subjectivation that were the focus of Foucault's own work on ethics. Arguably, Foucault's position on ethics and subjectivity can be understood as being well suited to the study of social movement organizations. Paul Veyne's (2010) book on Foucault has argued that, despite having left the Communist Party, Foucault maintained a great deal of sympathy for militant social activism. Rather than targeting broad political issues such as capitalist exploitation and imperialism, his own form of activism was directed 
towards more specific political targets such as campaigning for prisoners' rights and against the death sentence in the social movement organization, Le Groupe d'Information sur les Prisons (Deleuze, 2006; Welch, 2011). He also campaigned as part of Le Groupe d'Information sur la Sante, an SMO dedicated to health issues such as the right of women to have an abortion and the healthcare of immigrants (Foucault, 2000). It is clear from his interviews that his historical works offer no prescriptions for a particular way of life or a clear political agenda. However, he asserted that these works could provide impor- tant lessons for learning about social problems and the ways that these problems have developed historically. In this way, he argued, 'my position leads not to apathy but to a hyper- and pessimistic activism' (Foucault, 1997, p. 256). His genealogical approach to history entails a strategic conception of historical knowledge as part of a critical ontology of the present in order to locate what he termed 'points of reversibility' in tactical political struggles. In his genealogical studies he uncovered the existence of disciplinary techniques that form the modern docile subject, but it is his investigation of ethics and of social movements that more clearly revealed the 'points of reversibility' upon which alternative forms of active ethical subjectivity can develop.

This paper will now move from Foucault's historical analysis of the emergence of alternative arts of living to more recent exemplars that are to be found in modern social movement organizations. This analysis reveals four forms of 'ethical askesis', which are common to a number of different contemporary social movement organizations: (i) the askesis of 'bearing witness' and the 'true life'; (ii) the askesis of direct action in the creation of unconventional subjectivities; (iii) the care of the self and culture of asceticism; and finally, (iv) the use of pleasure in social movements. This selection of illustrative exemplars is chosen on the grounds that they serve to illustrate common forms of ethical askesis that are shared by a variety of social movement organizations. The analysis of these ethical practices shows that the ethical askesis of social movement organizations offer possibilities for 'micro-emancipation', a point to which we shall return in the final part of the paper. ${ }^{3}$

\section{Askesis i: Bearing witness in social movement organizations}

The practice of 'bearing witness' that we analysed earlier as a key element in Cynic self- transformation is a common practice in many contemporary social movement organizations. ${ }^{4}$ The idea of 'bearing witness' as a form of critique is bound up with a practical conception of the 'true life'. This theme can be found in ancient Cynicism, in the heretical sects of Christianity such as the Quakers and in modern social movement organizations such as Greenpeace, Amnesty International, the International Red Cross and others. Pulido (2003, p. 49) has argued that the activism that is characteristic of the work of social movements is part of a 'culture of truth'. Valverde (1999) has made a similar observation highlighting the very particular role of the practice of bearing witness as a means by which the memory of injustice and oppression is not forgotten. Practices of bearing witness concern the way in which memories are actively created. The significance of this practice is explained by Valverde (1999, p. 663) as follows: 'The fleeting presence of justice in the work of social movements is effected largely through remembering the injustices and genocides that must never be forgotten...' Bearing witness is an ethical practice of the self in which memory and justice become linked, which can be found in numerous social movement organizations.

One of the earliest organizations to pioneer modern forms of bearing witness was an 18th-century SMO, the Society for Effecting the Abolition of the Slave Trade, 
which was established by the Quakers in order to document and publicize the horrors of the slave trade (Dudai, 2008; Hochschild, 2005). This abolitionist SMO developed forms of bearing witness that are now commonplace including the crafting of slogans, pamphleteering and the use of consumer boycotts. Quaker activists employed their remarkable business skills in creating a powerful social movement organization that has been described as 'the first great social reform movement run mainly by businessmen' (Hochschild, 2005, p. 127). Adam Hochschild's (2005) exhaustive study of the anti-slavery movement highlights the remarkable fusion of skills that the Quaker community brought to the movement, deriving from their historical tradition of radical dissent as a Protestant sect combined with their renowned organizational skills that they had developed working as diligent businessmen.

Abolitionist activism has been an object of study in a special issue of the Administrative Science Quarterly (King \& Haveman, 2008) devoted to developing the links between organization theory and social movement theory. While ethical askesis was not the primary focus of this study of abolitionist SMOs, the study did address the notion of ethical askesis in its comparison of the activist practices of 'this worldly' church organizations such as the Quakers with the practices of 'other worldly' church organizations such as the Methodists. The study noted that 'this worldly' organizations developed new styles of activism, as exemplified by the legal activism of the Quaker community, which contrasted starkly with 'other worldly' SMOs that chose to 'focus on perfecting their souls and developing their relationships with God' (King \& Haveman, 2008, p. 501). This research found that geographical regions with a predominance of 'this worldly' organizations tended to have greater success in terms of abolitionist activism. Of particular interest for the purposes of the present argument is a clear link demonstrated between the Quaker practice of 'bearing witness' and the movement's success in developing 'this worldly' forms of activism.

'Bearing witness' is a particularly important practice within many modern SMOs. For instance, the Quaker activists who founded Amnesty International and Greenpeace incorporated the practice of 'bearing witness' as an integral aspect of their organizational cultures (Carmin \& Balser, 2002; Hopgood, 2006). Hopgood's (2006, p. 14) account of the organizational culture at Amnesty described the central role of this ethical practice in the following terms: 'Bearing witness became research, the documentation of individual cases and the recording of human rights abuses on a country by country basis. At the core of everything Amnesty has done lies this method of human rights activism.' Hopgood describes Amnesty International as a 'secular religion' that draws on Quaker practices such as bearing witness as being foundational to its organizational culture as well as for the establishment of its moral authority in the eyes of outsiders.

The modern environmental SMO Greenpeace also draws on Quakerism for its philosophical inspiration, especially with respect to the key importance of the values of peace, nonviolent action and its dedication to bearing witness (Carmin \& Balser, 2002). Several of its founding members were Quakers, who synthesized their religious and environmental beliefs into the unique activist philosophy that grounds both Greenpeace's strategy and its ethics. Carroll and Ratner (1999) explain that Greenpeace's ethics have developed from a diverse range of sources including Quakerism, deep ecology and Leninism. This environmental SMO has been a pioneer in the use of modern communications technologies such as television and the Internet to further amplify their activities in bearing witness. Carroll and Ratner (1999, p. 8) have explained that Greenpeace's unique strategy was forged in the organization's earliest campaigns against nuclear weapons testing, where 'The decision to sail a boat 
into the Alaska test zone was philosophically grounded in the Quaker tradition of "bearing witness", which continues to provide a rationale of Greenpeace- sponsored direct actions.' They have thus developed a highly effective bricolage (Campbell, 2005) of activist practices that have been synthesized to bear witness to acts of environmental devastation and to raise people's consciousness of ecological issues. We can therefore see that the askesis of 'bearing witness' appears to be a common type of ethical exercise that has appeared in different forms from the Cynics to modern-day SMOs.

\section{Askesis ii: Direct action in the creation of unconventional subjectivities}

Participation in direct action is a common kind of askesis of social movements in general (Melucci, 1988; Della Porta \& Diani, 2006; Polletta \& Jasper, 2001). Alberto Melucci's (1996, p. 379) commentary on social movements observed that the practice of direct action entails a constructive dimension to the extent that 'it seeks to create new institutions parallel to those being contested or resisted'. In a similar manner, Jean-Paul Sartre explained the significance of direct action, arguing that it 'expanded the field of the possible' (quoted in Ross, 2002, p. 32). Direct action is not only an important tactic for marginalized groups with few resources, but also with respect to an essential departure from the prevailing social norms in the creation of 'unconventional' forms of subjectivity and ways of life (Calhoun, 1993).

Numerous commentators on social movement organizations have observed that a common aim of participation in activism is the achievement of autonomous self-management (Böhm, Dinerstein \& Spicer, 2010; Calhoun, 1993; Deslandes \& King, 2006; Hardt \& Negri, 2009). In this respect, direct participation in selfgovernment may be understood as being both a means and an end of activism. Autonomous self-government is not simply assumed, but requires the creation of an active subject precisely to the extent that it requires direct participation. The link between identity and participation in direct action has been highlighted by numerous authors in a variety of ways, noting that the more successful social movements are in the construction of a collective identity, the more likely they are to engender participation (Della Porta \& Diani, 2006; Hunt \& Benford, 2007; Tarrow, 2011). Participation has been identified as being a crucial exercise for developing a sense of solidarity and belonging (Hunt \& Benford, 2007). Tarrow (2011, p. 152) has noted that a great deal of identity work is done within social movements to build a sense of solidarity through which these movements can mobilize activism. Many scholars have highlighted the importance of distinguishing clearly between 'them' and 'us' in collective identity formation, where 'exclusive identities' (Della Porta \& Diani, 2006; Goodwin, 2004) or 'oppositional identities' (Hunt \& Benford, 2007) were generally more successful in motivating direct participation in forms of activism. Hunt and Benford (2007) note that oppositional identities are often imposed from the outside, but are then drawn upon in the mobilization of the movement itself such as in the case of the gay rights movement.

The necessity of exclusivity in collective identity formation is debatable. The exemplary analysis of the May '68 social movement by Kristen Ross (2002) explains that one of its key motivating factors was its inclusiveness and the diversity of the protestors across social boundaries. Ross has identified numerous practices of direct action that are constitutive of activist subjectivity, including the mass march, the creation of the barricade, the street battle, the occupation of official state offices and buildings, workers' strikes and the creation of slogans. In addition to such practices she also identified a variety of practices that were peculiar to the events of May ' 68 
itself, and in particular the process of 'disidentification' that was aimed at radical equality, presenting a direct challenge to established forms of professional expertise. This entailed a rejection of existing social labels by means of which individuals understood themselves (such as the categories of the student, the worker, the intellectual, and so on). The process of disidentification was an ethical exercise designed to disrupt existing social categories and build solidarity in activism between diverse social groups.

In keeping with Ross's analysis, a more general empirical study by Hensby, Sibthorpe and Driver (2012) has found that a significant proportion of members of social movement organizations belong to more than one SMO and that they often participate in direct action with other allied organizations. Calhoun's (1993, p. 408) historical study of social movements noted that even in the social movements of the 19th century 'multiple membership, either simultaneous or serial [of different movements], was common'. More recent research into social movement organizations has been critical of the lack of participation by members where a link has been suggested between the growing professionalization of social movements and so-called 'cheque book activism' (Hensby et al., 2012; Jordan \& Malony, 2006). This criticism is precisely concerned with the danger that participation in a social movement can become little more than a branding exercise rather than being a genuinely selfforming activity. Now that we have examined the general ethical askesis of 'bearing witness' and 'direct action' we will turn to an analysis of the role of asceticism itself in SMOs.

\section{Askesis iii: The care of the self and asceticism}

A culture of self-sacrifice is a common theme in SMOs. Social movement organizations often require a great deal of self-discipline of their members that involves distinctive forms of 'care of the self'. Hopgood's (2006) account of the organizational culture of Amnesty International has observed that self-denial and personal sacrifice were seen as important organizational values. Hopgood (2006) highlights the origins of the organization in Quakerism, which is renowned for its disciplined working ethos and strict asceticism. The organization's members legitimize their 'culture of sacrifice' by explaining that life is far worse for the victims on behalf of whom they campaign. The moral authority of this SMO is grounded in its strict requirement of independence, and the suppression of emotions and personal opinions in the pursuance of its objectives. There is an expectation of 'self-disciplined persistence' among its members where successful campaigns are understood to be all too rare (Hopgood, 2006, p. 101).

The Occupy movement provides another excellent example of the significance of asceticism in SMOs. Occupy emerged in part from a call from the Adbusters group to launch a protest outside Wall Street on 13 July 2011, but this soon gathered momentum and many more encampments quickly sprang up elsewhere. Writing one year later, Paul Mason (2012) counted the formation of Occupy encampments in 962 cities across 85 different countries. Much of the existing work on Occupy has focused upon its tactical aspects, highlighting the fact that this movement has emerged in a variety of geographical spaces involving alliances with a wide range of social groups (Croatoan, 2012; Mason, 2012; Soule, 2012). Some have noted the novelty of the movement in developing new tactics of protest and 'weapons of the weak' (Soule, 2012; Treibitz, 2012). This includes the novel use of social media such as Twitter and Facebook in coordinating the protests, the decision to create their own autonomous media in disseminating their message, the release of video footage onto YouTube of 
the protests that immediately went viral, the 'human microphone' as a means of communication and learning, and a proliferation of occupation tactics for resisting house repossessions (Treibitz, 2012). ${ }^{5}$ In important respects the tactics that have been developed by the Occupy movement are instances of the kinds of ethical askeses that have been identified in the preceding analysis of 'direct action' and of 'bearing witness' to perceived injustice.

Several commentaries on the Occupy movement have examined the selfdiscipline of its participants, which are very revealing about the relationship between SMO tactics and their effects as practices of self-transformation. Ruggerio (2012, p. 16) argues that the Occupy movement's 'most radical message is its incitement to change ourselves, individually, in the workplace and socially'. Other commentators who have been directly involved in the movement have commented upon the practice of occupation as both a tactic and as a practice of self-transformation. Stronzake (2012, p. 118) describes the practice of occupation in the following way:

'In this process of concrete appropriate, reflection and new action, the human agent is transformed. The act of changing the world also transforms the human who is working for change... the shift in perspective, slowly occupies the person... The occupation is a first step in the learning process'.

Stronzake describes 'norms of conviviality' for everyday living that were established as the occupa- tion grew and were considered to be very much at the heart of the movement itself. These norms included practices of non-violence, caring for others and radical consensus making (Cornell, 2012; Maharawal, 2013). Many accounts highlight the affective and ascetic aspects of the occupation:

'...there is an ascetic element in the Occupy movement. By facing all the weathers in the open, the occupiers showed that they were willing to suffer to say their piece to Wall Street... suffering was a verification of the worth of the political message that is being expressed. Similar stories of ascetic suffering could be told at the other Occupy sites.' (Caffentzis, 2012, pp. 394-395)

The asceticism of suffering has also been addressed with respect to the role of nonviolence in the Occupy movement. McVeigh (2011) observed that the protest tactics required great self-discipline to remain nonviolent, particularly when the protestors were themselves subjected to heavy-handed treatment by the police. In Zuccotti Park activists developed exercises to help relax themselves and master their fears when tensions were high by forming massage and meditation circles (Schneider, 2011). Occupation has become a training ground in self-mastery, in terms of controlling one's passions, in caring for oneself and caring for others.

Asceticism has been identified in previous research as being essential to the development of capitalism (Halsall \& Brown, 2013; Weber, 1939); however, in SMOs such as Amnesty International and the Occupy camps this particular form of askesis has been turned towards ethical and emancipatory projects. Foucault's (2007b) own analysis of power has highlighted the important role of asceticism as a tactical point of 'reversibility' in the struggles of resistance against the apparatus of power, a point to which we shall return in greater detail below. We shall now turn to an analysis of a somewhat different kind of ethical askesis, where the care of the self has been conceived less in terms of ascetic deprivation and more in terms of the cultivation of the senses. 


\section{Askesis iv: The uses of pleasure in Slowfood}

An important dimension of ethical askesis can be characterized by what Foucault (1985) has termed 'the use of pleasure'. ${ }^{6}$ In contrast to the strict asceticism of the Occupy movement, the use of pleasure is perhaps better exemplified by the activism of the Slow Food movement. A recent study of the Slow Food movement has focused upon the institutional aspects of the movement's success, but it also makes tangential reference to the ethical askesis that provides the grounds for this movement (Van Bommel \& Spicer, 2011). This research explains that 'The quality of food and the sensual pleasure and enjoyment to be derived from eating (and drinking) was at the core of the movement in its early period' (Van Bommel \& Spicer, 2011, p. 1726). The practical exercises to intensify one's experiences of 'tasting' are precisely selfforming exercises that become the basis of the members' experience of subjectivity, as well as constituting the collective identity of the movement itself.

If we turn to Foucault's $(1985,1986)$ own genealogical analyses of self-care and ethical askesis, a significant portion of this work is devoted to the study of the dietary regimen and the uses of pleasure in Greco-Roman conceptions of self-mastery and ethics. Panagia (2009) has argued that the aims of the Slow Food movement and the exercises that it has developed for relearning how to taste and experience pleasure can be explicitly understood in terms of Foucault's concept of a 'care of the self'. Like Van Bommel and Spicer (2011), Panagia (2009) describes the success of Slow Food in terms of its novel organizational structure, building networks of alliances between local regional and international institutions, but the latter also highlights the importance of self- transformation in this movement, especially with respect to 'the education of the senses' (Panagia, 2009, p. 142), retraining people how to taste and how to enjoy the pleasures of 'conviviality'. The Slow Food movement has developed a series of exercises to transform their members' experience of taste and intensify their appreciation of the pleasure of food (SlowFood, 2010). This entails exercises to test and enhance one's sensory experiences including: (i) the testing of five taste sensations (sweet, salty, sour, bitter and umami); (ii) the testing of one's experience of different aromas in terms of their intensity and duration; (iii) the testing of one's experience of trigeminal sensations and texture; (iv) the testing of one's perception of the sound of foodstuffs (e.g. crunchy); and (v) the testing of one's visual sensations (e.g. smooth and rough). This series of exercises is designed to transform one's experience of taste and appreciation of the pleasure of food. This alternative care of the self and its emphasis on 'slowness' is explicitly directed in opposition to the fast food and fast lifestyles that have thrived under post-industrial capitalism where we have become 'enslaved by speed' (Panagia, 2009; SlowFood, 2009). This SMO does not reject capitalism in toto, but it challenges certain aspects of modern consumer capitalism and has endeavoured to create an alter- native relationship between consumption and the self where 'the slow diet weaves ethical relation- ships between self and convivial others, between self and cultural heritage, between self and biodiverse environment' (Paxson, 2005, p. 17). The distinctive use of pleasure within the Slow Food movement is both an ethical askesis and a key element in the mobilization of activism in the movement itself (Hayes-Conroy \& Martin, 2010).

In this analysis I have identified four forms of ethical askesis that are commonly found within contemporary SMOs: (i) bearing witness and the 'true life': (ii) direct action and the 'unconventional' self; (iii) the care of the self and asceticism; and (iv) the use of pleasure in social movements. The key findings of the above analysis are summarized in Table 1 in terms of the forms of ethical askesis, the 
organizational practices demanded by each particular askesis, and the particular SMOs that are founded on the use of such ethical exercises. The ethical exercises of these SMOs are not aimed at forming 'normalized' organizational subjects, but at cultivating 'unconventional' forms of subjectivity that present new ways of living and challenging the status quo. This analysis has provided only a limited inquiry into forms of subjectivation within social movement organiza- tions to give an indication of their significance as crucibles for the creation of alternative ethical practices. Future research could explore a more detailed analysis of processes of ethical subjectiva- tion within specific social movement organizations, the possibilities for which are discussed at the end of this paper. In the following section I turn to a discussion of how these ethical askeses can enrich the debate within organization studies of the notions of ethics and 'micro-emancipation' (Alvesson \& Willmott, 1992; Spicer, Alvesson \& Karreman, 2009).

Table 1. Forms of Ethical Askesis in SMOs.

\begin{tabular}{|c|c|c|}
\hline $\begin{array}{l}\text { Forms of } \\
\text { Askesis }\end{array}$ & Ethical Exercises in Organizations & Exemplary SMOs \\
\hline $\begin{array}{l}\text { i) Bearing } \\
\text { Witness }\end{array}$ & $\begin{array}{l}\text { Preservation of memories of injustice } \\
\text { Creating a culture of truth } \\
\text { Leading a 'true life' }\end{array}$ & $\begin{array}{l}\text { Amnesty International } \\
\text { Greenpeace } \\
\text { Gay and Lesbian SMOs } \\
\text { Society for the Abolition } \\
\text { of Slavery } \\
\text { Ancient Cynic school }\end{array}$ \\
\hline $\begin{array}{l}\text { ii) Direct } \\
\text { Action }\end{array}$ & $\begin{array}{l}\text { Public protesting and campaign } \\
\text { mobilization } \\
\text { Participating in autonomous self } \\
\text { management }\end{array}$ & $\begin{array}{l}\text { Occupy SMOs } \\
\text { Amnesty International } \\
\text { International Red Cross } \\
\text { Greenpeace } \\
\text { Society for the Abolition } \\
\text { of Slavery }\end{array}$ \\
\hline $\begin{array}{l}\text { iii) Care of Self: } \\
\text { Asceticism }\end{array}$ & $\begin{array}{l}\text { Suffering to speak } \\
\text { A culture of sacrifice }\end{array}$ & $\begin{array}{l}\text { Occupy SMOs } \\
\text { Amnesty International }\end{array}$ \\
\hline
\end{tabular}




\begin{tabular}{|l|l|l|}
\hline & $\begin{array}{l}\text { Mastering the discomforts of 'bearing } \\
\text { witness' and mastering fears } \\
\text { Practicing conviviality with others }\end{array}$ & Ancient Cynic schools \\
\hline iv) Use of & $\begin{array}{l}\text { Exercising to intensify the senses } \\
\text { Practicing the pleasures of } \\
\text { conviviality (e.g. slowness) } \\
\text { Preserving local knowledge of } \\
\text { convivial practices }\end{array}$ & Slowfood Society \\
\hline
\end{tabular}

\section{Remarks on Micro-Emancipation and the 'Undefined Work of Freedom'}

Foucault's genealogy of ethical askesis is part of a broader critical project to explore what he termed the 'undefined work of freedom' (Foucault, 1997, p. 316). This ethical project centres upon the transformation of the self and an experimental 'art of living'. Understanding ethics as an art of living has much to learn from social movement theorists who have already observed that SMOs are concerned with the creation of new ways of living and the 'freedom to be' (Cerulo, 1997; Melucci, 1989). The present paper has mapped out this 'freedom to be' in terms of the ethical askeses that are created by SMOs in their emancipatory projects to challenge the dominant apparatus of power.

We might compare the practice of micro-emancipation with Foucault's call for an ethics of 'pessimistic activism'. Whereas Alvesson and Willmott $(1992,2002)$ have focused upon sources of micro-emancipation from within the corporation, the present study has focused upon sources of micro-emancipation that have developed outside the corporation, where SMOs provide a rich source of possibility for the development of alternative ethical exercises as well as opening up tactical points of reversibility to dominant neoliberal forms of subjectivity. This paper has shown that the ethical askeses of SMOs can serve as a practical basis for organizational ethics and practices of micro-emancipation. This entails not only a tactical consideration of what Alvesson and Willmott (1992) call 'loopholes' within the dominant social order, but also practices that are them- selves a kind of self-forming exercise - an ethical askesis. In his commentary on the emancipatory potential of the Occupy movement, Zizek (2012, p. 82) has remarked upon the 'urgent need for new forms of discipline and organization'. He notes that this is precisely the point of Foucault's later works that investigate the way in which self-discipline can create an 'excess' that leads to a radical rupture in the hegemonic apparatus of power (Zizek, 2012, pp. 107-108).

Scholars within the field of organization studies have already raised the phenomenon of cynicism and 'cynical distance' as presenting a major obstacle to any emancipatory project within organizations (Fleming \& Spicer, 2003; Spicer et al., 2009). Most notably, Spicer et al. (2009, p. 542) have criticized the sub-genre of critical management studies for having a largely negative orientation, which they 
argue has led to a certain cynical distance to the practice of management 'without taking responsibility for what is replacing it'. The forms of ethical askeses that have been identified in the present paper are characteristic of the 'engaged' activism of SMOs, and to this extent such practices directly address and counter this problem of 'cynical distance'. In contrast to the 'cynical distance' that serves to undermine resistance to power within organizations, the alternative forms of self-discipline and practices of engaged activism that are found in SMOs can reactivate alternative projects for the cultivation of an active ethical self (Huault, Peret \& Spicer, 2014; Spicer \& Böhm, 2007; Böhm et al., 2008; King \& Haveman, 2008; Soule, 2012).

The genealogical approach to ethics offered by Foucault reveals how social movement organizations can become crucibles for the creation of new forms of living and ethical practices. In the terminology of organization studies such an approach serves to broaden the 'repertoire of alternatives' (Alvesson \& Willmott, 1992, p. 450) that are available for understanding issues of ethics and micro-emancipation in organizations. In this light, organization studies, and especially its conception of micro-emancipation, can be enriched by conceiving of micro- emancipation as a form of ethical askesis. This paper has revealed a range of alternative ethical exercises that could form the grounds for practices of micro-emancipation, including (i) bearing witness and the 'true life', (ii) direct action, (iii) the care of the self and asceticism, and (iv) the use of pleasure in social movements. Foucault himself highlighted the crucial link between power and subjectivity in the identification of 'reversible relationships' that provide points of resistance to prevailing regimes of governmentality (Foucault, 2005, p. 252). The concept of askesis is a key element of Foucault's conception of resistance to power, where he observed that 'in asceticism there is a specific excess that denies access to an external power' (Foucault, 2007b, pp. 207-208).

This inquiry has demonstrated that social movement organizations are crucibles for the creation of different ethical askeses that run counter to the prevalent hegemonic forms of neoliberal subjectivity. A path-breaking book devoted to exploring the links between organization studies and social movement research has already highlighted the need to investigate the 'processes by which people are transformed into agents able to challenge the status quo' (Scully \& Creed, 2005, pp. 312-313). The present study shows that SMOs have developed forms of ethical exercise to foster organizational subjectivities that act as points of resistance to power in their creation of unconventional ways of living.

\section{Conclusions: Possibilities for an Art of Living}

This paper has taken up the call within management and organization studies to explore Foucault's genealogy of ethics to provide a rich conceptual framework for studying organizational ethics in terms of a 'care of the self' and as an 'art of living' (Barratt, 2008; Starkey \& Hatchuel, 2002). The concern has already been raised that such calls may lack critical content and amount to little more than a kind of 'decaf resistance' (Contu, 2008). This paper highlights the importance of social movement organizations in the creation of ethical askeses that offer 'points of reversibility' in the hegemonic forms of power. The inquiry has revealed that modern social movement organizations are grounded in particular forms of ethical 'askesis' including (i) bearing witness and the 'true life', (ii) direct action, (iii) the care of the self and asceticism, and (iv) the use of pleasure. These organizational practices are ethical exercises that have been developed by SMOs to cultivate 'unconventional' forms of 
subjectivity (Calhoun, 1993) and create agents capable of challenging the status quo (Scully \& Creed, 2005).

The paper demonstrates that social movement organizations provide a fertile ground for developing alternative conceptions of ethics. In contrast to existing social movement research that has focused on the material and institutional resources on which SMOs build (Campbell, 2005; McAdam \& Scott, 2005), this paper has investigated the forms of self-discipline and the 'spiritual resources' (Soule, 2012) that SMOs mobilize in undertaking their work. Whereas existing research has focused upon discipline as a source of subjection to the apparatus of power, this inquiry has focused upon the specific forms of ethical self-discipline in SMOs that possess emancipatory potential. The contribution of this inquiry is threefold: (i) it provides a clear account of the concept of 'ethical askesis' as a practice of ethical self-discipline; (ii) it identifies four key forms of ethical askesis in social movement organizations as micro-emancipatory practices that create agents capable of changing the status quo; and (iii) it shows the potential of asceticism and other forms of askesis in the struggles of social movement organizations in the creation of new ways of organizing.

This paper raises a number of research questions and avenues for exploration for future studies in the area of organizational ethics. One avenue of future research is the investigation of how social movement organizations act as crucibles for the creation of alternative ethical askeses and forms of subjectivity, and how such askeses might act as points of resistance. Future research should develop more detailed empirical studies of the ethical practices of the self in specific SMOs. As Soule (2012) has already noted, the 'spiritual resources' of SMOs are in need of further investigation, and one path for undertaking this is through an inquiry into the ethical askeses that help cultivate these resources. The work on 'cynical distance' could be fruitfully explored, drawing upon the concept of askesis by investigating the relationship between cynical distance in organizations and forms of identity work outside the workplace, especially in social movement organizations. Avenues of inquiry for future research could also examine the extent to which the unconventional subjectivities created by SMOs act as points of resistance to the neoliberal apparatus of power.

\section{Acknowledgements}

I would like to thank the anonymous reviewers and the editorial team for their constructive comments and insightful suggestions. I would also like to thank the following scholars for their feedback in the development of the ideas presented in this paper: Silvia Jordan, Albrecht Becker, Martin Messner, Steffen Böhm, Chris Land, Torkild Thanem, Christian Huber and Rita Samiolo.

\section{Funding}

This research received no specific grant from any funding agency in the public, commercial, or not-for-profit sectors.

\section{Notes}

1. This conception of cynicism is quite different from the commonsense conception of modern cynicism. In contrast to ancient Cynicism, variants of modern cynicism may well operate as a cultural adjunct of power, allowing for its uninterrupted operation. See Fleming and Spicer (2003) for an exemplary commentary on this form of 'cynical distance'. This ancient school of Cynicism can be understood as an expression of 'strong' cynicism, in contrast to more modern 
forms of 'weak' cynicism which do not demand radical social critique of its practitioners (e.g. see Sloterdijk, 1988).

2. It is true that Weber deals with the anti-institutional, charismatic aspects of religious social movements in other works, notably in his The Sociology of Religion (1922/1993) and in Economy and Society (see Weber, 1991), where he defines charismatic leadership very much in terms of its power to de-institutionalize the prevailing social order, and its capacity for a 'transvaluation of values'. In his works on religion he notes that charisma played an important role in Protestant sects and their use of lay preachers whose right to speak came from a state of grace rather than from a church ordinance. However, he is more concerned to point out that Protestantism ultimately succeeded in doing away with magic and hence charisma, leaving behind the shell of 'worldly asceticism', which would find an important role as a spiritual mirror for the division of labour (e.g. see Weber, 1939, pp. 102-125).

3. I focus on these forms of ethical askesis for illustrative purposes, while recognizing the necessity of a more detailed empirical study of ethical subjectivation that might be found in specific social movement organizations.

4. We might note that the etymology of the term 'protest' is derived from the Latin pro testis - 'bear witness'.

5. These tactics include squatting in repossessed housing, the construction of 'occupied real estate agencies' and the deployment of 'For Squat' signs (Treibitz, 2012).

6. The use of pleasure was identified by Foucault $(1985,1986)$ as a major component of Greek and Roman exercises of self-mastery (askeses). He noted that a crucial difference between ancient ethics and modern ethics is that in the former the focus was less on forbidding pleasures that were good or bad in themselves, but rather that one did not become a slave to one's pleasures (e.g. in dietetics and sexual practices). His genealogical studies uncovered a wide variety of ethical systems which developed radically different exercises for the use of pleasure and the related cultivation of self-mastery.

\section{References}

Alvesson, M., \& Willmott, H. (1992). On the idea of emancipation in management and organization studies. Academy of Management Review, 17, 432-464.

Alvesson, M., \& Willmott, H. (2002). Identity regulation as organizational control: Producing the appropriate individual. Journal of Management Studies, 39, 619-644.

Bardon, T., \& Josserand, E. (2011). A Nietzschean reading of Foucauldian thinking: Constructing a project of the self within an ontology of becoming. Organization, 18, 497-515.

Barratt, E. (2008). The later Foucault in organization and management studies. Human Relations, 61, 515- 537.

Bluhdorn, I. (2006). Self-experience in the theme park of radical action? Social movement and political articulation in the late-modern condition. European Journal of Social Theory, 9(1), 23-42.

Böhm, S. Spicer, A., \& Fleming, P. (2008). Infra-political dimensions of resistance to international business: A Neo-Gramscian approach. Scandinavian Journal of Management, 24, 169-182.

Böhm, S. Dinerstein, A., \& Spicer, A. (2010). (Im)possibilities of autonomy: Social movements in and beyond capital, the state and development. Social Movement Studies, 9(1), 17-32. 
Burrell, G. (1988). Modernism, postmodernism and organizational analysis: The contribution of Michel Foucault. Organization Studies, 9, 221-235.

Caffentzis, G. (2012). In desert cities. In K. Khatib, M. Killjoy \& M. McGuire (Eds.), We are many: Reflections on movement strategy from occupation to liberation (pp. 389-398). Oakland, CA: AK Press.

Calhoun, C. (1993). New social movements of the early nineteenth century. Social Science History, 17, 385- 427.

Campbell, J. (2005). Where do we stand? Common mechanisms in organizations and social movement research. In G. Davis, D. McAdam, W. Scott \& M. Zald, Social movement organization theory (pp. 41-68). Cambridge, UK: Cambridge University Press.

Carmin, J., \& Balser, D. (2002). Selecting repertoires of action in environmental movement organizations. Organization and Environment, 15, 365-388.

Carroll, W., \& Ratner, R. (1999). Media strategies and political projects: A study of social movements. Canadian Journal of Sociology, 24, 1-34.

Cerulo, K. (1997). Identity construction: New issues, new directions. Annual Review of Sociology, 23, 385-409.

Chan, A., \& Garrick, J. (2002). Organization theory in turbulent times. Organization, 9, 683-701.

Clegg, S. (1994). Weber and Foucault: Social theory for the study of organizations. Organization, 1(1), 149-178.

Clegg, S. (1998). Foucault, power and organizations. In A. McKinlay \& K. Starkey (Eds.), Foucault, management and organization theory (pp. 29-48). London: SAGE Publications.

Contu, A. (2008). Decaf resistance: On misbehavior, cynicism, and desire in liberal workplaces. Management Communication Quarterly, 21, 364-379.

Cornell, A. (2012). Consensus: What it is, what it is not, where it came from and where it must go. In K.Khatib, M. Killjoy \& M. McGuire (Eds.), We are many: Reflections on movement strategy from occupation to liberation (pp. 163-173). Oakland, CA: AK Press.

Covaleski, M., Dirsmith, M., Heian, J., \& Sajay, S. (1998). The calculated and the avowed: Techniques of discipline and struggles over identity in big six public accounting firms. Administrative Science Quarterly, 43, 293-327.

Croatoan (2012). Who is Oakland: Anti-oppression activism, the politics of safety, and state occupation. In K. Khatib, M. Killjoy \& M. McGuire (eds) We Are Many: Reflections on Movement Strategy from Occupation to Liberation (pp. 81-87). Oakland, CA: AK Press.

Davidson, A. (2011). In praise of counter-conduct. History of the Human Sciences, 24(4), 25-41.

Deleuze, G. (2006). Foucault and prisons. In Two regimes of madness: Texts and interviews, 1975-1995 (pp.272-281). London: Semiotext(e).

Della Porta, D., \& Diani, M. (2006). Social movements: An introduction, 2nd edition. Oxford: Blackwell.

Deslandes, A., \& King, D. S. (2006). Autonomous activism and the global justice movement: Aesthetic reflexivity in practice. Journal of Sociology, 42, 310-327.

Dilts, A. (2011). From 'entrepreneur of the self' to 'care of the self': Neo-liberal governmentality and Foucault's ethics. Foucault Studies, 12, 130-146.

Dudai, R. (2008). The long view: Human rights activism, past and present. Journal of Human Rights, 7, 299-309. 
Findlay, P., \& Newton, T. (1998). Re-framing Foucault: The case of performance appraisal. In A. McKinlay \& K. Starkey (Eds.), Foucault, management and organization theory (pp. 211-229). London: SAGE Publications.

Fleming, P., \& Spicer, A. (2003). Working at a cynical distance: Implications for power, subjectivity and resistance. Organization, 10, 157-179.

Foucault, M. (1982). The subject and power. In H. L. Dreyfus \& P. Rabinow, Michel Foucault: Beyond structuralism and hermeneutics (pp. 208-226). Hemel Hempstead, UK: Harvester Press.

Foucault, M. (1985). The history of sexuality, vol. 2: The use of pleasure. London: Penguin.

Foucault, M. (1986). The history of sexuality, vol. 3: The care of the self, London: Penguin.

Foucault, M. (1994). The politics of health in the eighteenth century. In P. Rabinow (Ed.), Michel Foucault: Power (pp. 90-105). London: Penguin.

Foucault, M. (1997). On the genealogy of ethics: An overview of work in progress. In P. Rabinow (Ed.) Michel Foucault: Ethics, subjectivity and truth (pp. 253-280). London: Penguin.

Foucault, M. (2000). Summoned to court. In J. Faubian (Ed.), Michel Foucault: Power (pp. 423-425). London: Penguin.

Foucault, M. (2005). The hermeneutics of the subject: Lectures at the College de France 1981-1982. New York: Picador.

Foucault, M. (2007a). What is critique? In The politics of truth (pp. 41-81). London: Semiotext(e).

Foucault, M. (2007b). Security, territory, population: Lectures at the College de France 1977-1978. Basingstoke: Palgrave-Macmillan.

Foucault, M. (2008). The birth of biopolitics: Lectures at the College de France 19781979. Basingstoke: Palgrave-Macmillan.

Foucault, M. (2011). The courage of truth: Lectures at the College de France 19831984. Basingstoke: Palgrave-Macmillan.

Goodwin, J. (2004). Review essays: What must we explain to explain terrorism? Social Movement Studies, 3, 259-265.

Goodwin, J., Jasper J., \& Polletta, F. (2007). Emotional dimensions of social movements. In D. Snow, S. Soule \& H. Kriesi (Eds.), The Blackwell companion to social movements (pp. 413-432), 2nd edition. Oxford: Blackwell Publishing.

Grey, C. (1994). Career as a project of the self and labour process discipline. Sociology, 28, 479-497.

Hadot, P. (1995). Philosophy as a way of life. Oxford: Blackwell Publishing.

Halsall, R., \& Brown, M. (2013). Askesis and organizational culture. Organization, 20, 233-255.

Hancock, P. (2008). Embodied generosity and an ethics of organization. Organization Studies, 29, 1357-1373. Hardt, M., \& Negri, A. (2009). Commonwealth. Cambridge, MA: Belknap Press of Harvard University Press.

Hayes-Conroy, A., \& Martin, D. (2010). Mobilising bodies: Visceral identification in the Slow Food movement. Transactions of the Institute of British Geographers, 35, 269-281.

Hensby, A., Sibthorpe, J., \& Driver, S. (2012). Resisting the 'protest business': Bureaucracy, post-bureaucracy and active membership in social movement organizations. Organization, 19, 809-823.

Hochschild, A. (2005). Bury the chains: The British struggle to abolish slavery. London: Pan Books. 
Hopgood, S. (2006). Keepers of the flame: Understanding Amnesty International. Ithaca, NY: Cornell University Press.

Huault, I., Perret, V., \& Spicer, A. (2014). Beyond macro- and micro-emancipation: Rethinking emancipation in organization studies. Organization, 21, 22-49.

Hunt, S., \& Benford, R. (2007). Collective identity, solidarity and commitment. In D. Snow, S. Soule \& H. Kriesi (Eds.), The Blackwell companion to social movements (pp. 433-458), 2nd edition. Oxford:Blackwell Publishing.

Ibarra-Colado, E., Clegg, S., Rhodes, C., \& Kornberger, M. (2006). The ethics of managerial subjectivity. Journal of Business Ethics, 64, 45-55.

Iedema, R., \& Rhodes, C. (2010). The undecided space of ethics in organizational surveillance. Organization Studies, 31, 199-217.

Jasper, J. (1998). The emotions of protest: Affective and reactive emotions in and around social movements. Sociological Review, 13, 397-422.

Jasper, J., \& Poulson, J. (1995). Recruiting strangers and friends: Moral shocks and social networks in animal rights and anti-nuclear protests. Social Problems, 42, 493512 .

Jordan, G., \& Malony, W. (2006). Letting George do it: Does Olson explain low levels of participation? Journal of Elections, Public Opinion and Parties, 16, 115-140.

King, M., \& Haveman, H. (2008). Antislavery in America: The press, the pulpit, and the rise of antislavery societies. Administrative Science Quarterly, 53, 492-528. Knights, D. (2002). Writing organizational analysis into Foucault. Organization, 9, 575-593.

Kosmala, K., \& McKernan, J. (2011). From care of the self to care for the others: Neglected aspects of Foucault's late work. Accounting, Auditing and Accountability Journal, 2, 377-402.

Loacker, B., \& Muhr, S. (2009). How can I become a responsible subject? Towards a practice-based ethics of responsiveness. Journal of Business Ethics, 90, 265-277.

McAdam, D., McCarthy, J., \& Zald, M. (1996). Comparative perspectives on social movements. Cambridge, UK: Cambridge University Press.

Maharawal, M. (2013). Occupy Wall Street and a radical politics of inclusion. Sociological Quarterly, 54, 177-181.

Mason, P. (2012). Why it's kicking off everywhere: The new global revolutions. London: Verso.

McAdam, D., \& Scott, W. (2005). Organizations and movements. In G. Davis, D. McAdam, W. Scott, \& M. Zald (Eds.), Social movement organization theory (pp.140). Cambridge: Cambridge University Press.

McGee, M. (2005). Self-Help Inc. Makeover culture in American life. Oxford: Oxford University Press.

McKinlay, A. (2002). Dead selves: The birth of the modern career. Organization, 9, 595-614.

McKinlay, A. (2012). 'Little cogs': Bureaucracy and the career in British banking, c. 1900-1950. In Thomas Diefenbach \& Rune Todnem By (Eds.), Reinventing hierarchy and bureaucracy - From the bureau to network organizations (pp. 31-57). Bingley, UK: Emerald Group Publishing.

McMurray, R., Pullen, A., \& Rhodes, C. (2010). Ethical subjectivity and politics in organizations: A case of health care tendering. Organization, 18, 541-561.

McVeigh, R. (2011). How Occupy Wall Street works: Why it will remain nonviolent. Foreign Affairs Magazine. 
Melucci, A. (1988). Getting involved: Identity and mobilization in social movements. In B. Klandermans, H. Kriesi \& S. Tarrow (Eds.), International social movement research: A research annual (pp. 329-348). Greenwich, CT: JAI Press.

Melucci, A. (1989). Nomads of the present: Social movements and individual needs in contemporary society. Philadelphia, PA: Temple University Press.

Melucci, A. (1996). Challenging codes: Collective action in the information age. Cambridge, UK: Cambridge University Press.

Miller, P., \& O'Leary, T. (1987). Accounting and the construction of the governable person. Accounting, Organizations and Society, 12, 235-265.

Miller, P., \& Rose, N. (1988). The Tavistock Programme: The government of subjectivity. Sociology, 22, 171-192.

Panagia, D. (2009). The political life of sensation. Durham, NC: Duke University Press.

Paxson, H. (2005). Slow food in a fat society: Satisfying ethical appetites. Gastronomica: The Journal of Food and Culture, 5(1), 14-18.

Polletta, F., \& Jasper, J. (2001). Collective identity and social movements. Annual Review of Sociology, 27, 283-305.

Pulido, L. (2003). The interior life of politics. Ethics, Place and Environment, 6, 4652.

Randall, J., \& Munro, I. (2010). Foucault's care of the self: A case from mental health work. Organization Studies, 31, 1485-1504.

Rose, N. (1990). Governing the soul: The shaping of the private self. London: Routledge.

Ross, K. (2002). May ' 68 and its afterlives. London: University of Chicago Press. Ruggerio, G. (2012). Editor's Note. In N. Chomsky, Occupy. London: Penguin Books.

Sage, G. (1990). Power and ideology in American sport: A critical perspective. Champaign, IL: Human Kinetics Books.

Savage, M. (1998). Discipline, surveillance and the 'career': Employment on the Great Western Railway 1833-1914. In A. McKinlay \& K. Starkey (Eds.), Foucault, management and organization theory (pp. 65-92). London: SAGE Publications. Schneider, N. (2011). From Occupy Wall Street to Occupy Everywhere. The Nation, 10 October 2011.

Scully, M., \& Creed, W. (2005). Subverting our stories. In G. Davis, D. McAdam, W. Scott, \& M. Zald (Eds.), Social movement organization theory (pp. 310-332). Cambridge, UK: Cambridge University Press.

Sloterdijk, P. (1988). Critique of cynical reason. Minneapolis: University of Minnesota Press.

SlowFood (2009). The Slow Food Manifesto: International movement for the defense of and the right to pleasure, http://www.slowfood.com/filemanager/official_docs/SF_Manifesto_ENG.pdf.

SlowFood (2010). To the Origins and Taste, http://www.slowfood.com/education/filemanager/resources/Origini_Gusto_eng.pdf.

Snow, D., Rocheford, E., Worden, S., \& Benford, R. (1986). Alignment processes, micromobilization and movement participation, American Sociological Review, 51, 464-481.

Soule, S. (2012). Social movements and markets, industries and firms. Organization Studies, 33, 1715-1734.

Spicer, A., Alvesson, M., \& Karreman, D. (2009). Critical performativity: The unfinished business of critical management studies, Human Relations, 62, 537-560. 
Spicer, A., \& Böhm, S. (2007). Moving management: Theorizing struggles against the hegemony of management. Organization Studies, 28, 1667-1698.

Starkey, K., \& Hatchuel, A. (2002). The long detour: Foucault's history of desire and pleasure, Organization, 9, 641-656.

Stronzake, J. (2012). People make the occupation, and the occupation makes the people. In K. Khatib, M. Killjoy, \& M. McGuire (Eds.), We are many: Reflections on movement strategy from occupation to lib- eration (pp. 115-122). Oakland, CA: AK Press.

Tarrow, S. (2011). Power in movement: Social movements and contentious politics, 3rd edition. Cambridge, UK: Cambridge University Press.

Townley, B. (1994). Reframing human resource management: Power, ethics and the subject at work. London: SAGE Publications.

Treibitz, J. (2012). The art of cultural resistance. In K. Khatib, M. Killjoy \& M. McGuire (Eds.), We are many: Reflections on movement strategy from occupation to liberation (pp. 325-336). Oakland, CA: AK Press.

Valverde, M. (1999). Derrida's justice and Foucault's freedom: Ethics, history, and social movements. Law and Social Inquiry, 24, 655-676.

Van Bommel, K., \& Spicer, A. (2011). Hail the snail: Hegemonic struggles in the Slow Food Movement. Organization Studies, 32, 1717-1744.

Veyne, P. (1993). The final Foucault and his ethics. Critical Inquiry, 20, 1-9. Veyne, P. (2010). Foucault: His thought, his character. Cambridge: Polity Press.

Weber, M. (1922/1993). The sociology of religion. Boston, MA: Beacon Press. Weber, M. (1939/1992). The Protestant ethic and the spirit of capitalism. Abingdon, UK: Routledge. Weber, M. (1948/1991). From Max Weber: Essays in sociology, H. H Girth \& C. Wright Mills (Eds.). London: Routledge.

Weiskopf, R., \& Willmott, H. (2013). Ethics as critical practice: The 'Pentagon Papers', deciding responsibly, truth-telling, and the unsettling of organizational morality. Organization Studies, 34, 469-494.

Welch, M. (2011). Counterveillance: How Foucault and the Groupe d'Information sur les Prisons reversed the optics. Theoretical Criminology, 15, 301-313.

Wray-Bliss, Edward (2002). Abstract ethics, embodied ethics: The strange marriage of Foucault and Positivism in labour process theory. Organization, 9, 5-39.

Zizek, S. (2012). The year of dreaming dangerously. London: Verso Books.

\section{Author biography}

Iain Munro is Professor of Leadership and Organizational Change at the Newcastle University Business School, UK. He has research and teaching interests in Foucauldian and post-structuralist approaches to the study of organization, information warfare and systems thinking. He has published in journals including Organization, Organization Studies, Human Relations and the Journal of Business Ethics. 